\title{
Land grabbing by villagers? \\ Insights from intimate land grabbing in the rise of the industrial tree plantation sector in Guangxi, China
}

\begin{abstract}
:
While most studies focus on large-scale foreign corporate-dominated land grabbing, relatively smallscale land acquisitions initiated by local villagers receive much less attention. This reflects that the scale, the identity of investors and a simplified role of villagers tend to take precedence in analyses of land grabbing. However, the common dichotomies of "large vs small”, "outside vs local actors" and "victim vs grabber" might be problematic and even misleading, considering the case of Guangxi.

In China's Guangxi province, with the rise of the industrial tree planation (ITP) sector, some villagers have gained control over the land from local or nearby village collectives and have become owners of ITPs. Over the course of these practices, grabbers are not from "outside", but "local villagers" themselves. They are then able to control the land, which was originally collectively used and benefit from it at the expense of their neighbours and kin, under certain contexts. Such land control change is called intimate land grabbing.

This case demonstrates that: (1) small-scale land grabs are not necessarily less significant than largescale ones; (2) land grabs dominated by local actors sometimes have more serious adverse impacts on local communities; and (3) villagers can also be grabbers, rather than simply victims, or otherwise resisters. In bringing the issue of intimate land grabbing into the debate, this paper argues that the importance of a land grab is neither represented by its scale nor the identity of the grabber(s), but by its de facto consequences, especially the distribution of the costs and benefits. This piece hopes to highlight the importance of dynamics of social relations around land and production processes in analyses of land grabbing and contribute to a fuller picture of global land grabbing.
\end{abstract}

\section{Highlights:}

- In Guangxi, some villagers grabbed land at the expense of their neighbours and kin.

- This paper focuses on dynamics of land-based changes and production processes.

- Small-scale land grabs are not necessarily less significant than large-scale ones.

- Land grabs dominated by local actors sometimes have more serious adverse impacts.

- Villagers can also be grabbers rather than simply victims, or otherwise resisters.

\section{Key words:}

Intimate land grabbing, villagers, small-scale, local actors 


\section{Introduction}

In the era of the global land rush, corporations, especially transnational ones, are highly visible. In the current literature on land grabbing, ${ }^{1}$ these corporations are framed as key grabbers - acquiring large tracts of land in processes that are more or less facilitated by state actors. The resulting corporate control over land is for diverse profit-seeking activities, including offshore food/non-food production, natural resource extraction and speculation (Borras Jr et al. 2011, White et al. 2012).

Meanwhile, villagers are usually the victims of the land deals, ${ }^{2}$ losing control over land they previously used. ${ }^{3}$ Most of the villagers in question are dispossessed, or even displaced, where "their land is needed, but their labour is not" ( $\mathrm{Li} \mathrm{2011,286).} \mathrm{In} \mathrm{response,} \mathrm{these} \mathrm{affected} \mathrm{villagers} \mathrm{choose} \mathrm{to} \mathrm{resist} \mathrm{these} \mathrm{land}$ deals in either overt or covert ways in some cases (Borras and Franco 2013), or to adapt in others (Mamonova 2015).

These are all quite important issues, and the literature has paid them due attention. The missing piece, however, is the fact that land grabs are not only large-scale and (transnational) corporate-dominated, but also occur at relatively small scales, and are initiated by local villagers. ${ }^{4}$ Thus, correspondingly, local villagers are not always "victims" and "resisters", but sometimes grabbers themselves as when they acquire land from their own and/or nearby villages, leading to the dispossession of their fellow villagers or kin. In this paper, inspired by the idea of "intimate exclusion" (Hall et al. 2011, 145-146), such land grabbing is called intimate land grabbing. ${ }^{5}$

The industrial tree plantation (ITP) sector is among the most booming sectors in Southern China. ${ }^{6}$ In the Guangxi province, with the rise of the ITP sector, some villagers gained control over the land from local or nearby village collectives and have become owners of eucalyptus tree plantations. Within these practices, grabbers are not from "outside", but are "local villagers" themselves. They are able to gain access to land that previously belonged to collectives and benefit from it at the expenses of their neighbours and kin. Why and how did these villagers take and maintain control over land? What are the impacts and implications of these land grabs? Are these intimate land grabs, occurring at small scales and initialled by local villages, necessarily less significant than those large-scale and corporatedominated ones?

To answer these questions, this paper unpacks the dynamics of individual-dominated ITPs in Guangxi, in terms of their land acquisitions and consequences. The analysis is mainly based on an extensive set of primary data collected from my two fieldwork trips during the spring of 2015 and 2016, including 65 in-depth interviews with the villagers in 6 counties using snowball sampling. These sites, selected based on the preliminary fieldwork in 2014 and secondary data online, show distinct dynamics with the rise of the ITP sector. ${ }^{7}$ In addition, observations drawn from the fieldwork conducted in 2014 and 2017

\footnotetext{
${ }^{1}$ There are different interpretations of land grabbing by different authors for distinct purposes, as pointed out by Dell'Angelo et al. (2017). This paper follows working definition of Borras et al (2012) on land grabbing, which focuses on the effect control of land. This implies that land grabbing, which constitutes land control change, is bound to result in the dispossession of previous land users.

2 In this paper, 'villagers' is used to describe socially differentiated rural residents.

${ }^{3}$ Although few villagers might benefit under certain context (see Oberlack et al. 2016, Xu 2018)

${ }^{4}$ Friis et al (2016) have already studied small-scale land grabs.

${ }^{5}$ In this sense, those grabbers from outside (the community) and those villagers who do not acquire local land at the expense of kin and fellow villagers then are not considered as intimate land grabbers.

${ }^{6}$ In this paper, ITPs not only refer to those large-scale plantations owned/controlled by corporations, but also include large-scale individual-owned and small-scale villager-owned ones. Among these, eucalyptus trees (especially the fast-growing species E. grandis and E.urophylla) have become the most popular in Guangxi, and are thus the main focus in my study.

${ }^{7}$ The sites include one county where foreign investors are actively involved in the ITP sector, one county where a state-owned farm is engaged, four counties where independent planters are dominated. But it does not mean that each county I visited only contains one type of investment in the ITP sector. Each targeted county features several
} 
in Guangxi and secondary data collected from reports, official statistics, and academic articles are employed to strengthen the analysis.

By analysing these intimate land grabs in the ITP sector in Guangxi, this paper does not intend to make generalized claims on small-scale villager-dominated land acquisitions in the whole region or worldwide or overstate the importance of intimate land grabbing vis-à-vis large-scale corporatedominated land grabbing. Instead, this piece aims to bring the issue of intimate land grabbing into the debate and point to possible dynamics which are emerging and critical but have not yet received sufficient attention. In doing so, it rethinks the analytical emphases of the current literature and political debates on land grabbing (i.e. what de facto represents the importance of a land grab).

The remainder of this paper is organised as follows: the following section introduces some key academic debates on land grabbing; the third section presents and examines the conjunctures of such land grabbing (why grab land? why local villagers? why locally?); the fourth section focuses on the mechanisms of these individual-dominated land grabs (how to gain and maintain control over land); the fifth section explores the impacts of these land grabs in comparison with corporate-dominated ones.

\section{Debates on land grabbing within crop booms}

Prior to detailed analysis of the empirical case, key debates on land grabbing in response to a crop boom are introduced in this section. As Hall (2011) points out, when a crop boom takes place, there is a rapid increase of changes in land-use for the cultivation of that certain crop in a given area. This is not only a process of massive land-use change, but is often followed by land acquisitions/land grabs in varying ways and at different scales. These land acquisitions include a dynamic change of land control: when someone gained access to land, those who were previously using land lost their part of or full control. This aligns with the definition of land grabbing put forward by Borras et al. (2012), that land grabbing is essentially a form of 'control grabbing': "grabbing the power to control land and other associated resources such as water in order to derive benefit from such control of resources” (Borras et al. 2012, 850).

In the current literature on land grabbing within a crop boom, most studies have focused on large-scale and corporate-dominated (especially transnational) land control and land use changes, where the common result was either expulsion of or resistance by the affected villagers. ${ }^{8}$ Would that mean, however, that intimate land grabs, occurring at smaller scales without the engagement of agribusiness, and which do not lead to massive expulsion or overt resistance, do not also merit research? To disaggregate this question, subsequent questions must be posed. First, is the importance of a land grabbing case associated with the number of hectares it covers? This is a debate on the scale of land grabbing. Second, does a land grab dominated by a foreign corporation have more serious impacts than one dominated by local actors? This is linked with the identity and power of a grabber. Third, when encountering a crop boom, are the affected villagers only left to be victims or resisters? This is a question about the role of villagers. Taking these questions a step further, what are the key elements of land grabbing that should be counted and what might be misleading? And thus, how can we analyse a land grab?

\subsection{Large vs small}

Recently, the scale of a given land acquisition has become a vital selection benchmark of many media reports and academic studies. This means that large-scale land grabs attract more attention and more critiques. As clearly pointed out by Oya $(2013,515)$ : “[i]n debates about impact and generally about the efficiency and equity of land use, the 'small vs large' dichotomy looms large. Most studies and

combined dynamics (e.g. there are villages where local villagers acquire land to plant eucalyptus trees when foreign investors have already built relatively large-scale ITPs).

${ }^{8}$ In addition to displacement and resistance, in few cases, there are other possible livelihood outcomes (e.g. improving a few villagers’ wellbeing), according to Oberlack et al. 2016. 
reports criticising 'land grabs' make frequent recourse to general arguments in favour of smallholder farming and against large-scale farming."

The scale does actually matter. Because the size not only shows explicitly the area a land grab covers, but also implies the size of the population it might affect and the ability of the investor(s) to access to resources and information. ${ }^{9}$ This means that the scale is one of critical measurements that partly reflect the extent and consequences of a land deal. However, over-focusing on scale, or what Edelman (2013, 488) vividly described as "fetishizing of hectare" can be problematic and even misleading.

First, this is related to the accuracy and reliability of data on land areas per se. On the one hand, as it is difficult for researchers and journalists to collect first-hand data on land areas, most of the data that is used, and reused, is provided by actors who are deeply involved in the process of land-based changes. Thus, there is a tendency to over- or under- report the scale based on the distinct interests of a particular actor. On the other hand, land grabs are not static and always developing into actual production as announced. In reality, a large number of land grabs have either failed or have never been realized due to different reasons. ${ }^{10}$ Because of this, analysing based on unreliable and outdated data can be fraught.

Second, scale is not the primary element in evaluating the importance of a case. Not only land scale, but also land quality and geographic location matter (Scoones et al. 2013). Moreover, as Borras et al. (2012) remind us, such over-emphasis reflects a "too land-centric" view. It misses some other critical elements, for instance, the amount of capital involved (Borras et al. 2012, 850) and the power relations behind the scene (Edelman 2013). When a large-scale land deal occurs, previous land users might have better livelihood sources (e.g. off-farm work) in the certain contexts, and then be willing to lease land with relatively reasonable compensations (Xu 2018). This situation is not always worse than a smallscale land grab, wherein villagers lost their land as their primary income source and were not able to be employed by the grabber or find work in any other sector. In this sense, large-scale land grabs are not necessarily more important than small-scale ones.

Third, over-focusing on large-scale land deals will, in turn, (re)shape the trajectory of land grabs. More specifically, large-scale land deals are bound to receive more attention. Therefore, large-scale projects do not always go beyond official announcements; instead they are changed, suspended or terminated due to outright social resistance in host countries or various economic, political or legal issues (Borras and Franco 2013). Furthermore, due to their high visibility, large-scale land grabs have to comply - at least in theory - with national and international norms and standards under certain contexts. On the contrary, small-scale land grabs often slip under the radar and are much less exposed to public control. Therefore, they are more likely to hit the ground running and bring serious social-political and environmental impacts and should never be ignored.

In short, small-scale land grabs are no less important than large-scale ones. This is not to say that the scale of land acquisitions should be overlooked. Instead, I argue that it is problematic to solely focus on the issue of scale and use it as the only criteria for case selection in investigations and reports, while ignoring the dynamics of social relations around land and production process on the ground.

\subsection{Outside vs local actors}

As for land grabbers, those from outside, especially from foreign countries are spotlighted. ${ }^{11}$ Land investments dominated by external actors are usually critiqued as being harmful to local development.

\footnotetext{
${ }^{9}$ These points are made both implicitly and explicitly when some researchers critique large-scale land acquisitions (e.g. De Schutter 2011).

${ }^{10}$ For example, the actual scale of Chinese land investments in Africa is much less than reported (Brautigam and Ekman 2012).

${ }^{11}$ In this paper, outside land grabbers include those from foreign countries and those domestic enteral actors. Although domestic ones are equally and even more active within the land rush (Borras and Franco 2012), majority of existing literature still focuses on foreign land investments, what Zoomers $(2010,429)$ called the "foreignisation
} 
Because these land investments, particularly when the land is used for food production and/or extraction of land-based resources, tend to lead to social and environmental costs externalised to land recipient regions, and mostly, if not only, benefit grabbers (De Schutter 2011). These arguments are valid and critical. However, it does not mean that the negative impacts caused by these land grabs are necessarily a result of the identity of the grabbers. Rather, an attempt to assess a land grab based on the grabber's local/outside identity actually reflects a xenophobic trend and might be deceptive.

Because the essential assumption behind such "local vs outside" dichotomy is that the investments dominated by local actors might have spill-over effects, while outsiders do not have any interest in local development. Yet, as Oya (2013) put it, there is no evidence to show that compared with outsiders, local grabbers always do less harm, or perhaps even good, to local development.

Meanwhile, always criticising outsiders and defending local actors might be problematic. When a land grab is initiated by a local elite and facilitated by the local state, it does not necessarily have less significant impacts on the local community than a land acquisition dominated by an external individual farmer via land lease based on negotiation with villagers. This reveals an element to be taken into account that is more important than the identity of grabbers, namely, the power relations of control change.

Power relations are embedded in social-political-economic contexts, and associated with the control power of a grabber on one side of the spectrum and of targeted landowners on the other. Under certain context, external grabbers are not necessarily more powerful than local ones due to two reasons.

First, both external and local grabbers are not homogeneous, but highly differentiated - ranging from state-owned corporations, to private companies to individual entrepreneurs. Different groups of grabbers have different capital sources, and correspondingly, distinct power situations. Meanwhile, these different groups of grabbers might choose different ways to exercise their power during land control change, via economic means, extra-economic means or both at once. An individual farmer who leased land in a foreign country is not as powerful as a state-owned company that expropriated land in a local village. So, it can be problematic to put investors/grabbers under a large umbrella according to their countries of origin, for example simply as Chinese.

Second, compared with outsiders, local investors usually have additional power as it pertains to legitimacy in both seeking and maintaining control over land at an intimate scale due to their social bonds. Hall et al. $(2011,146)$ explained that, "social proximity freights exclusion with moral weight and has consequences for personal standing". The examples analysed in the Hall et al. study, showed that is difficult for villagers to request their kin to pay a market price as land rent when they are actually using their land, or to evict them when an outsider is willing to pay a higher price. Moreover, when big investors, as outsiders, are faced with high costs on maintaining land access and production processes due to everyday forms of resistance from affected villagers as is usually the case (Scott 1977), local investors/grabbers can benefit from both geographic and social proximity.

Therefore, although local grabbers are often overlooked, their negative impacts on local community are not necessarily less than outsiders. Instead of focusing on whether a grabber is an outsider or a local insider, what should be emphasised is the power exercised by a grabber during control change and the actual resulting impacts on the local community embedded in a certain context.

\subsection{Victims vs grabbers}

Land grabbing, closely linked with Marx's "primitive accumulation” and David Harvey's "accumulation by dispossession", is a process through which peasants are separated from their means of production. On the one hand, it enables capitalists to increase their wealth and power via the control

of space”. So, the studies and arguments that are engaged during the discussion in this section are mainly about these foreign land grabbers. 
over the means of production, while, on the other hand, it creates "double free labour" (free of property and free to sell labour) serving as cheap wage labour (Lenin 1982, 130-131). Thus, land grabbing facilitates the ongoing capital accumulation in both ways.

Then villagers, who are the previous users of land, are always portrayed as victims within this process. Villagers have been observed to be directly dispossessed in India to make way for Special Economic Zones (Levien 2012), in Guatemala for the development of sugarcane and oil palm industries (AlonsoFradejas 2012), in Ethiopia for export-oriented food production (Moreda and Spoor 2015), and in many other places for various other land-uses.

However, as Borras et al. $(2012,850)$ remind us, "analytically and empirically land grab does not always require expulsion of peasants from their lands; it does not always result in dispossession". Land control can be gained without direct enclosure, but under schemes of out-growers and with villagers incorporated (White et al. 2012). When land grabs do not directly dispossess villagers, those villagers can still become more vulnerable in one way or another due to the long-term impacts of large-scale land investments: they might go bankrupt during the competition with big investors, as is the case in Ukraine (Mamonova 2015); they can become excluded because of the squeeze of the upstream and downstream markets and their limited or lack of control over the process of production and outputs, as is the case in Bolivia (McKay and Colque 2016); or they could continually be trapped in a cycle poverty even when they are incorporated due to their unfavourable terms of inclusion, as is the case in Indonesia (McCarthy 2010).

Hence, even when villagers are not outright dispossessed during land acquisitions, contemporary academic studies and the media have, for the most part, observed them to be adversely affected to varied extents. Additionally, some villagers have been observed to resist these land deals in diverse forms, ranging from individual covert forms of everyday resistance (Moreda 2015), individual overt "rightful resistance" (O'Brien et al. 2006), and collective overt movements (Edelman 1999, Martiniello 2015), to more mixed and dynamic forms (McAllister 2015, Alonso-Fradejas 2015). However, it does not mean that the role of villagers is limited to this.

As highlighted by Borras and Franco (2013, 1724), as well as by Hall et al. (2015), villagers are not homogeneous. They have distinct resource endowments, including land control, labour conditions, financial resources and social relations. Based on these factors, villagers might be affected differently. Some villagers are able to adapt and find their own niches within the land-use and land control changes, such as in Ukraine (Mamonova 2015). In few cases, a group of villagers even benefit from the change (Xu 2018, Oberlack et al. 2016). Moreover, in some cases, villagers have already become differentiated and spilt into distinct social classes due to their different relationships to the means of production. For highlanders in Indonesia, "[i]nitial landownership was unequal and overtime, efficient farmers were able to accumulate land and capital and pay workers to expand their farms and profits" (Li 2014, 7). Such social differentiation was further deepened with crop booms. When some villagers were forced to sell their land due to the failure of their cash crop production, other villagers are able to obtain additional land and become more prosperous.

In this sense, when encountered with crop booms and the massive land-use and land control changes that follow, villagers do not necessarily lose out and become passive victims. Under certain contexts, villagers can even become land grabbers themselves, as has happened in Indonesia (Li 2014). Some villagers have been heavily dispossessed by their neighbours. These outcomes remind us that before simply pronouncing villagers as victims of land grabs, a more careful examination of the actual wins and losses during the process, based on different resource endowments of villagers, is required.

In short, besides large-scale transnational land deals, those small-scale land grabs initiated by villagers, such can also be quite important and deserve in-depth investigation. The importance of a land grab is represented not by its scale, or the identity of the grabbers, but by the de facto consequences, especially 
the distribution of the social-economic and environmental costs and benefits of a land acquisition. In the same vain, when analysing a land grabbing case, instead of focusing on the hectares and the identity of grabbers, the dynamics of social relations around land and production process should be key analytical elements. These factors are spotlighted by the case of intimate land grabs in Guangxi.

\section{Background: the conjunctures of the intimate land grabbing}

Intimate land grabs in Guangxi emerged at certain conjunctures, namely (1) the rise of ITP sector in the region, and (2) agrarian transformation in rural China. These land grabs occurred with the rise of the ITP sector in Guangxi. On one side, land use change enabling the monoculture of eucalyptus trees is the target of the land control change. In other words, the crop boom is a key factor that stimulates the emergence of these land grabs. On the other side, the features of the ITP sector (e.g. social-economic and environmental impacts) are closely associated with the reactions of the affected villagers, which further (re)shape the trajectory of land control and land-use changes. Meanwhile, agrarian transformation in rural China is not only the specific structural and institutional context in which these intimate land grabs emerged, but also a critical factor that leads to the intended and unintended outcomes of intimate land grabs.

\subsection{The rise of the ITP sector}

Over the past two decades, the ITP sector has expanded rapidly and massively in Guangxi. As shown in Figure 1, ITPs began slowly in the 1980s, gained momentum in the 1990s, and have spread dramatically since then. Before the year 2000, eucalyptus areas increased slowly, by about 1.3 times from 43.2 thousand ha in 1977 to 57.6 thousand ha in 1990. From 1990 to 2010, the area covered by eucalyptus trees skyrocketed, expanding twenty-nine times to a total of 1653.3 thousand ha. Currently, Guangxi is the top area for eucalyptus in China. ${ }^{12}$

Figure 1 area of eucalyptus trees in Guangxi (1000 ha)

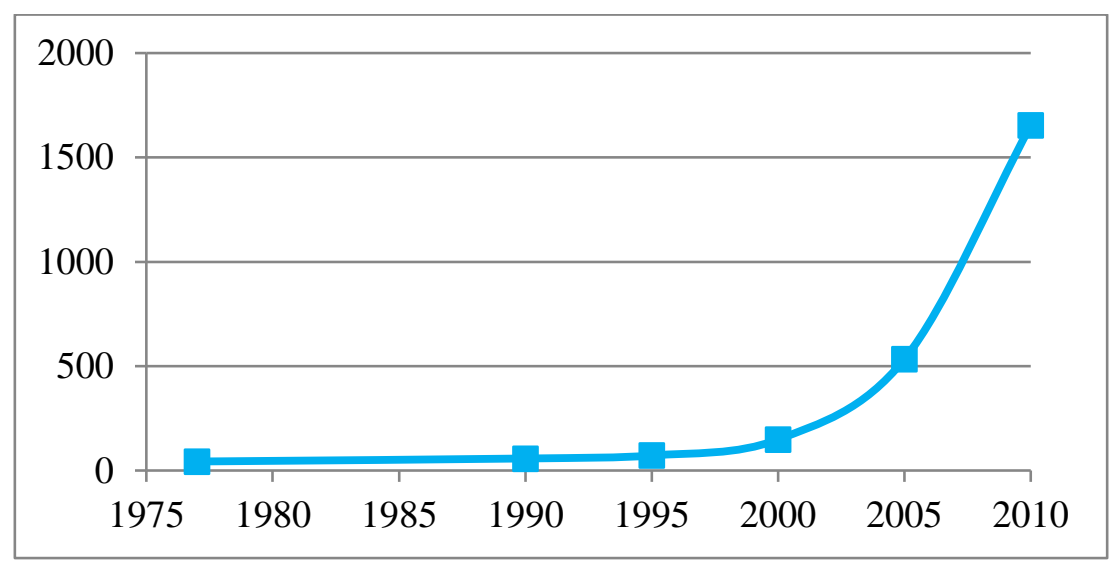

Source: 1977-2005 data (Pang 2006), 2010 data (Wei 2011).

Both overseas and domestic companies are involved in the Guangxi ITP sector. Foreign investors (Stora Enso from Finland and APP from Indonesia) mainly specialise in paper products, while domestic ones, including state-owned forest farms, mainly specialise in timber/board/furniture products. The commodities produced from the ITPs are mainly destined for Chinese domestic consumption.

The ITP sector has key features that have important economic, agronomic and environmental contradictions (Lungo, Ball, and Carle 2006). Fast-wood tree crops are quite attractive economically, considering the huge domestic demand of the products made from them - a demand that is caused by

${ }^{12}$ However, the expansion of ITPs may have slowed down since 2013 when the Guangxi Forest Department issued a policy to generally reduce the area of eucalyptus trees in Guangxi to 4 million mu (equal to 0.27 million Ha) by 2020. (http://www.forestry.gov.cn/main/392/content-737409.html accessed on 16 January 2017) 
country's fast urbanisation rate and remarkable population growth. Together with the features of fast returns on investment and regeneration ability, ${ }^{13}$ investments in ITP tend to yield considerable monetary profits. As a villager in Guangxi commented, "planting eucalyptus trees is like (constructing) a bank there” (Field notes on 6 March 2015). In practice, however, not everyone benefits from these activities.

Environmentally, the ITP sector has significant effects on local ecologies, where its ability for fast growth is linked to sharp demands of water and soil nutrition (Calder et al. 1997, Calder 2003). In Guangxi, ITPs are often criticised as "water pumps" and "nutrition pumps" by local people, due to their negative effects on local hydrological and soil conditions. Moreover, the industrial production mode, especially the use of chemical fertilizers and herbicides, accelerates environmental destruction.

Social impacts of ITPs are highlighted by the fact that they generally require less labour than other cash crops (e.g. sugarcane). ${ }^{14}$ Job opportunities in the ITP sector are limited and temporary, and are concentrated during the planting and harvest stages. ${ }^{15}$ In cases where peasants are separated from their land, its low labour demand almost eliminates the chances of them being incorporated into the sector as wage labourers. Thus, in the ITP sector, expulsion is likely to be more complete, as has taken place in Ecuador (Gerber and Veuthey 2010) and in Brazil (Kröger 2012). Alternatively, the non-intensive labour demand makes it possible for villagers (i) to keep ITPs on their land as supplementary income while doing farm or off-farm jobs at the same time, or (ii) to become large-scale ITP holders based on family management and with little and even no wage-labour employment. In this sense, the ITP sector can provide villagers with additional livelihood options, as it has done in Vietnam (Sikor 2011), and at the same time opportunities for the individual-based investments in the sector, as with the following case in Guangxi.

The rise of the ITP sector, especially big companies' investments in it, motivated a few individual villagers to engage in the land grabbing, as illustrated by one villager who leases over $110 \mathrm{mu}$ of forestland in the village, ${ }^{16}$

I used to do migrant work outside. When the Finnish company (Stora Enso) came to our village and leased the forestland at the price of 8 Yuan per mu per year, I felt it is not worthwhile. I think it is better that I cultivate by myself. At that time, the timber is quite cheap with only 260280 Yuan per ton... (I) never thought the price would increase to the level today (at around 600800 Yuan per ton). (Field notes, 18 March 2015)

But such motivation will not be automatically transformed into land grabbing practices. These individual villager-initiated land grabs occurred within certain social-institutional contexts, which conditioned their land control, and continuously (re)shaped the trajectory of their land grabs. Thus, it is important to look into the agrarian transformation that is relevant to our understanding the dynamics of the intimate land grabs in the southern part of this country.

\subsection{Agrarian transformation and rural differentiation}

This part focuses on (i) conditions and institutions of land in rural Guangxi, especially undistributed and collective-owned forestland, which is the targeted land involved in this type of land grabbing, (ii) rural-urban migration and its implications on the labour supply in the countryside, as well as on the

\footnotetext{
${ }^{13}$ Eucalyptus can be logged in 4-6 year rotations. And one eucalyptus tree can generate two or three shoots after logging naturally. (Interviews with eucalyptus specialists in Guangxi University on 13 March 2014 and 17 March 2014)

${ }^{14}$ According to my interviews with villagers in Guangxi in 2015 and 2016.

${ }^{15}$ The trees need labor just in the first 6 months and the harvest season (about 2 days per year per mu on average) according field notes in 2014.

${ }^{16} \mathrm{Mu}$ refers to a unit for the measurement of land - $15 \mathrm{mu}$ equals 1 hectare. And the forestland was mostly commonly used and had not yet been contacted to villagers before the boom of the ITP sector, which will be explained in the next section.
} 
household incomes of villagers, and (iii) the rural differentiation based on the above land-labour condition changes that then fostered and shaped the trajectory of the intimate land grabs.

Before the rise of the ITP sector, most of the forestland had been degraded in Guangxi ever since the destruction of a big area of forests for food production in the 1950s-1970s (Li 2008, 27). ${ }^{17}$ However, degradation does not mean that the forestland plots were not used. According to my fieldwork in Guangxi, a group of villagers used to "live on cutting firewood" (Field notes, 3 March 2016). This means that the land control and land use change of forestland plots are bound to have significant impacts on this group of villagers in terms of their livelihood.

As for property rights and institutions, different from farmland, most collectively owned forestland had not been contracted to individual families under the household responsibility system (HRS) reform in the 1980s, and was still the property of the collective. Even if this was the case in theory, in practice, some villagers customarily "owned" some undistributed "waste" forestland plots. In most villages, "who claims the wasteland (forestland) owns the land" (Field notes, 6 March 2015). Customary ownership is commonly agreed. Put another way, once someone in the village reclaimed a piece of forestland, the land plot is then believed to be "owned" by his/her household; no one else in the village will use it. These pioneers of sorts are usually those with rich labour resources in the household and extra money for the venture, sometimes, even with special social positions (e.g. village leaders) to have better access to information. In 2008, forestland reform was introduced to formally distribute and clear the user rights of the collective forestland. ${ }^{18}$ Even so, most of the land plots have already been used or occupied by local villagers or external investors before this reform, especially since the rise of the ITP sector and the issue of reforestation subsidy policy in the early-2000s. ${ }^{19}$

Amidst these changes, the rural land market in China was gradually opened (Spoor 2012, 187). In the mid-1990s, rural land rental market emerged in some pilot counties and developed rapidly (Zhang, Ma, and $\mathrm{Xu}$ 2004). ${ }^{20}$ Then in 2008, the central state deepened its land reform, further loosening and simplifying land transfer procedures. ${ }^{21}$ According to the Law on the Contracting of Rural Land (2008), community members have the priority to lease the land owned by their village collectives.

Along with the conditions of land control, labour conditions also changed in rural China, in the context of rural-urban migration. Millions of villagers - usually the young and the physically strong ones referred to as "peasant workers" (nongmingong) - left their villages to seek jobs in the cities. Such internal migration is always temporary and seasonal, yet it has still taken away a large number of labourers in rural areas. Using the example of Guangxi, the total number of rural-urban migrate workers reached 11.65 million by the end of 2015, which equals more than one fifth of the total population there. ${ }^{22}$

\footnotetext{
${ }^{17}$ According to $\mathrm{Li}$ (2007), those less hilly and rocky forestland plots (around 0.7 million ha) were used for grain and sugarcane cultivation, leaving other non-arable forestland plots in a state of "waste". Later, even under the state-led reforestation movement in the 1990s aiming at recovering the waste forestland, these "waste" forestland plots were still "underused" with several pine or acacia trees planted here and there. Such degradation was partly related to the slow economic returns (usually more than 15 years) of the tree crops (pine and acacia), which provides few incentives for forestland investments.

${ }^{18} \mathrm{http}: / /$ www.gov.cn/jrzg/2012-10/29/content_2252860.htm , accessed on 22April 2016

${ }^{19}$ Reforestation subsidy, sponsored by Chinese central government, is intended both to stop the abandonment of amble land due to the immigration from rural to urban areas and, besides, to improve the eco-environment at the same time. And during the first round (from 2003 to 2011), the subsidy included 150 kilos rice per mu and 50 Yuan in cash for 8 years.

${ }^{20}$ What could be transferred are land user rights, and the selling and buying of land remains forbidden (Zhang et al. 2004, 464).

${ }^{21}$ Central Document No. 10 (2008)

${ }^{22}$ Source: http://www.gov.cn/xinwen/2015-12/11/content_5022563.htm , accessed on 16 January 2017
} 
Internal migration, whether a forced survival option in the context of the current capitalist system (Bernstein 2010) or an active livelihood choice of the villagers to "form twin legs and/or crutches" (Huang, Yuan, and Peng 2012, 164), has significantly changed the labour-land relation in rural China. Such change has proven to be a great fit for the development of labour-saving crops such as eucalyptus. However, at the same time, it contributes to social-economical differentiation among villagers, regarding their distinct labour conditions and inflows of remittances.

Following changes of land and labour conditions in rural areas, villagers tend to become differentiated, although the sources of that differentiation continue to be debated. Some scholars theorise that the differentiation is related to non-farm work. According to Zhang $(2012,469)$, "the primary source of rural inequality is access to non-farm incomes”. Similarly, Jacka (2017) observed that the social differentiation was led by outmigration. Then, such differentiation is demographic and circular, although it may later contribute to a more polarised form of differentiation. Meanwhile, other scholars argued that farming plays a more important role in rural differentiation. As Hairong and Yiyuan (2015) argued, Chinese rural differentiation is associated with land control changes that occur through diverse channels. Thus, transformation is an economic and permanent process. Common to the two types of differentiation is that, in both cases, it leads to inequality among villagers in access to and control over livelihood resources (e.g. natural capital, economic capital and social capital), which later becomes the key dynamic of the intimate land grabbing.

\section{Mechanisms of land control by intimate land grabbers}

In the conjunctures discussed above, some villagers were able to gain control over land for the cultivation of eucalyptus via distinct mechanisms. To acquire land, these intimate land grabbers employed both economic and extra-economic means, as summarised in Table 1. These practices enable some villagers to accumulate at the expense of their neighbours and kin, including (i) enclosing previously commonly-used land based on their resources (particular labour and social resources) they possessed to exclude their fellow villagers from using, (ii) leasing collectively-owned forestland earlier or at a price that others cannot afford, (iii) lending money to landholders in exchange for control over land-use and outputs, and (iv) getting involved in the up-/down-stream business to enhance their control over the land.

Table 1 Distinct mechanisms of individual villager-dominated land grabbing

\begin{tabular}{cccc}
\hline Type & Mechanisms & $\begin{array}{c}\text { Number of } \\
\text { interviewed villagers }\end{array}$ & Scale (mu) \\
\hline Extra-economic & $\begin{array}{c}\text { Customary } \\
\text { occupation }\end{array}$ & 36 & $0.5-200$ \\
\hline Economic & Leasing & 20 & $7-500$ \\
& $\begin{array}{c}\text { Loans } \\
\text { Control of up-/down- } \\
\text { stream business }\end{array}$ & 15 & Hundreds \\
\hline
\end{tabular}

Source: author’s fieldwork in Guangxi in 2015 and 2016

The first mechanism, customary occupation, is more common, normally taking place everyday (piecemeal), by stealth, and mostly at relatively smaller scales, as shown in Table 1 . These practices occurred with the rise of the ITP sector in the early-2000s and before the 2008 forestland reform. ${ }^{23}$ Under this scheme, these grabbers controlled undistributed and collectively owned forestland through customary occupation. They are those villagers whose households have abundant labour resources to

\footnotetext{
${ }^{23}$ During the forestland reform, these grabbers, then, are granted certificates (lin quan zheng) to assure their user rights.
} 
claim degraded forestland, and access to information about profitable land-use. As explained by a villager in a focus group discussion when I asked about the uneven distribution of forestland in their village: "if you have better labour conditions, and are physically stronger, you can occupy more land. (Because) (forest-)land is not yet distributed" (Field notes, 11 March 2016).

Despite having suitable labour conditions, most villagers can only grab land at a very small scale (usually less than 10mu), while a small group of villagers is able to get access to more land, reaching as much as hundreds of mu. Common land is limited. This small group of villagers is able to obtain more land as they started the practice earlier than others. Why did these villagers seize the chance and spend their time and labour force claiming these degraded land plots, which, before the eucalyptus boom, were thought to be "valueless and unwanted by people" (Field notes, 13 March 2016), while other did not? The answer is closely allied with villagers' ability to access information. This is the case of an ex-leader of a village I visited in the March of 2016. He acquired information about the rise of the ITP sector from friends in county government, and then became the first one to claim the undistributed and collectively owned forestland. In this way he gained control of around $200 \mathrm{mu}$ of forestland, and as time went by, others took notice. A few villagers also started to claim the land, but at a much lesser scale (around tens mu).

In this sense, only those villagers who have the social connections to access information and then sufficient labour resource are able to seize the opportunity to gain control over restricted land via customary occupation. When these villagers control the land, others are inevitably dispossessed, excluding from original and (possible) future use of the land.

The latter three mechanisms draw mainly from market power. To directly control the land, some villagers leased land from their community, facilitated by local authorities (i.e. village cadres). ${ }^{24}$ These villagers' land acquisitions, which exclude the land access of their fellow villagers and kin, ${ }^{25}$ are mainly based on their privileged financial capital. Their economic capital advantage comes mostly from nonfarm work. Of the 20 villagers that leased land from the collectives that I interviewed in Guangxi in 2015 and 2016, all of them are and/or were doing non-farm work in town and/or urban areas, in a range of jobs, including wage work, transportation, construction and trade businesses, as the main source of their households' incomes. This implies that access to profitable non-farm work is vital for these grabbers in order to gain direct control over land through this mechanism.

Among these land tenures, seventeen are completely independent landholders, with the scale of their ITPs ranging from $7 \mathrm{mu}$ to $500 \mathrm{mu}$. Three villagers shared part of the landholdings, at scales of $30 \mathrm{mu}$, $50 \mathrm{mu}$ and 200mu respectively, with their few friends or kin (1 to 3 people) through cooperation.

In addition to land leases, there are also indirect ways for individual villagers to control land-use and products. One way is using loans, which is less common, but exists nonetheless. For example, a villager who already had a $150 \mathrm{mu}$ ITP lent money to another planter, enabling him buy chemical inputs, in exchange for the contract to purchase his trees at a certain price after four years (Field notes, 18 March 2015). Another way is to control the land indirectly by engaging in one or more upstream or downstream businesses, including transporting trees and timbers, preliminarily processing, and trade (i.e. being

\footnotetext{
${ }^{24}$ According to Law on the Contracting of Rural Land (2008), to lease the collectively-owned land, the contract should be approved by at least $2 / 3$ of the villagers. Normally, it is the village cadres who coordinate this process. Meanwhile, these cadres, usually as the representatives, sign the contract.

${ }^{25}$ When the fellow villagers/kin lost their access to the collectively-owned land, they usually received little or even no compensate. According to my interviews in 2015 and 2016, the individual investors usually gave land rent directly to village collectives. While only the villagers of one villages (among all the 11 villages the I visited) stated that they received around 100yuan per capita every year (Field notes, March 2016). The other villagers either said that they have not heard about the rent or explained that the land rent is left to the collectives for public activities.
} 
brokers). ${ }^{26}$ In this way, villagers can become included under better terms and enhance their control power.

These practices are not completely independent. Some grabbers used multiple methods to obtain control over land. The villager who lent money to control the outputs produced by other villagers also leased land from his village to directly control a 150mu ITP. Six villagers I interviewed who leased land to build ITPs are also engaged in up- and downstream ITP sector businesses concurrently.

These land grabs occurred in a much smaller scale than those carried out by Stora Enso (82.26 thousand ha) and APP (around 100 thousand ha ITPs) (StoraEnso 2016, Liu 2010). Accordingly, the amount of capital involved in their investment is much less compared to the big companies. However, this does not mean that these intimate grabbers necessarily have less control power. The ease and firmness with which they can control land is embedded in regulation and legitimacy based on their identities as villagers, and on their geographic and social proximity. Legally, villagers are endowed with the priority to contract their collective lands according to regulation. Thus, their land claims are legitimised. Socially, these villagers, mostly elites, usually have better connections with cadres who are in charge of land distribution and transfer, which can make their land access easier than those "outside" investors.

When APP and Stora Enso encountered with resistance, and as a response either stopped acquiring land in Guangxi since 2008 (APP) or reduced its land control from 90.2 ha in 2014 to 86.3 ha in 2016 (Stora Enso), ${ }^{27}$ these intimate land grabbers are able to maintain their control over land more firmly. On the one hand, due to their intimate relations with their fellow villagers, compared with those "outside" investors, villagers were usually met with far less overt resistance. On the other hand, they were able to better manage covert forms of resistance, including pilferage, arson, sabotage and encroachment. ${ }^{28}$ They are geographically close to the land plots under their control. When such instances of resistance erupt, they are able to quickly intercept the practices, as explained by a villager who controls $150 \mathrm{mu}$ ITPs:

If the (plantation) is not in the same village, it is very difficult to manage. When the trees are planted outside, no one can watch it if other people steal trees. Right? People will not steal when they know it belongs to an individual. And it will be troublesome if the trees are burnt during the Qingming Festival ${ }^{29}$. When trees are planted in the place where I can watch, if the trees are burnt, I can just find several people to put out the fire. (Field notes, 18 March 2015)

In this way, compared with big companies, intimate land grabbers do not have weaker, but sometimes even stronger, control power. However, this does not mean that their land control is static and that their investments always pay-off. In reality, their investments are also full of risks. During the long growth cycle, villagers also have to deal with marker volatility and the uncertainty of agronomic conditions (e.g. the weather). One "intimate land grabber" told me that due to the typhoon a year earlier (in 2014), his trees were all "broken" and he had suffered a great loss (Field notes, 20 March 2015). Due to such losses, some grabbers have reduced and even gave up their land control.

\footnotetext{
${ }^{26}$ Brokers are those who purchase trees from other planters, harvest, and then trade the outputs.

${ }^{27}$ See http://www.yicai.com/news/4730287.html accessed on 21 June 2016; http://www.beihai365.com/bbs/m/iphonetest/read.php?tid=3443840\&onlylz=1 , accessed on 25 April 2016; and Sustainability Report. In Stora Enso's Annual Report 2015: p 47.

${ }^{28}$ These covert forms of resistance are not only pointed out by both villagers and the owners of ITPs, but also my observation during the fieldwork. Such covert forms of resistance, sometimes can lead to a loss of investors. For example, a villager told me that the total 10000mu ITPs in her village invested by external investors (both foreign companies and individual external bosses) are hardly harvested due to frequent tree theft and arson (Field notes, 1 March 2016).

${ }^{29}$ According to the culture, people will burn the spiritual money when people visit ancestors' graves on the hills in Qingming Festive.
} 


\section{Consequences of intimate land grabbing}

With changes in land control and land-use, these intimate land grabs inevitably affected local communities economically, socially and environmentally. Although these intimate grabs occurred at a relatively small scale and are initialled by local actors, compared with large-scale and (external) corporate-dominated ones, their impacts are not necessarily less significant.

\subsection{Land control change and labour employment}

Some of these factors are associated with land control change. When the user rights are changed and concentrated in the hands of a few villagers, fellow villagers who previously used the land are consequentially dispossessed. In this instance, these villagers have lost at least part of their original source of income and are additionally deprived of the possibilities to expand their livelihoods (i.e. to plant eucalyptus trees), based on the land that otherwise was commonly used.

Moreover, when these fellow villagers lost the control over the previously collectively owned and freely used land, but are not able to get employed, the situation might get worse. ${ }^{30}$ According to my fieldwork in Guangxi, these individual villager-dominated land investments sometimes create even fewer job opportunities for local populations than external company-dominated ones, due to their particular production modes.

Whereas corporation-dominated production depends entirely on wage labour, these intimate grabbers can, at least partly, exploit family labour. According to my interviews, when the amount of land control is less than $30 \mathrm{mu}$, production practices (including seeding, weeding, and fertilizing, but excluding logging) are usually carried out by family members. When the scale of the ITP is over $30 \mathrm{mu}$, the intimate grabbers tend to hire seasonal labour to sow, plant, weed, fertilize, and log, just as the big companies do. An illustration of this is given by a villager I interviewed in 2015 . He contracted $500 \mathrm{mu}$ of forestland from his own collective and I asked him whether he was able to manage such a large-scale plantation. "If (you) have money," he replied, "it does not matter how many hectares (you cultivate). Work can be done by hired people” (Field notes, 13 April 2015).

As for labour employment, foreign companies prefer local wage workers. An employee of a foreign company explained:

The wage of the local workers is higher. But the majority of the employed is from local... (Because) considering the costs of transport and discontinuity, the total cost of (employing) outsiders is higher. When it rains, the boarding cost will be 50-60 yuan per day per capita. If the rain lasts long, the project will stop (Field notes, 19 March 2016)

Contrastingly, some intimate land grabbers prefer migrant workers. Because they, due to the smaller scale of their ITPs, are less concerned about continuity, but more about pure wage costs, as explicated by a villager who owned 300 mu of ITPs:

Normally (I employed workers) from Yunnan and Guizhou Province. These migrant workers work harder, and they are cheaper. There is one leader of these migrants from Yunnan. He talks with the bosses (the investors), and then goes back to take a group of migrants. He will also gain some money from it. We call him the broker. It is more secure (for us) to employ through him. And (we) only need to pay him. (Field notes, 13 April 2015).

This implies that these grabbers at times take more economic rather than moral factors into consideration. Diverging from the assumptions of moral economists (Scott 1977), in which villagers act based on principles of reciprocity and collective moral, in practice, these villagers act out of their own interests, which are based on their class relations (i.e. relations with the means of production). As a

\footnotetext{
30 There are exceptions when villagers have better alternatives (e.g. off-farm work in urban areas) and actively get excluded (see Xu 2018).
} 
result, during the land control change, intimate grabbers dispossessed their fellow villagers, similar to large-scale external investors, while their production sometimes is observed to include fewer, not more local populations.

\subsection{Land-use change and environmental impacts}

Meanwhile, some impacts are related to land-use change, more specifically the features of the particular crop. As introduced in part 3.1 of this paper, land-use change towards eucalyptus trees will inevitably change the ecological environment of the neighbouring land plots (e.g. hydrological, nutrition and sunshine condition). Such change, in turn, will have significant adverse influence on fellow villagers' farming. As one villager illustrated, "there is no other crop that can be grown besides the eucalyptus trees.”(Field notes, 30 March 2015). Thus, after the land use change, these villagers' yields tend to decrease. This means their income from farming further declines.

While, surprisingly, intimate land grabbing is not necessarily more environmental-friendly, but sometimes observed to have serious negative impacts on local environment in Guangxi. This is mainly because of a few intimate land grabbers' intensive production practices. During the cultivation, some local individual investors stated that they use chemical inputs intensively, as "chemical fertilizers work efficiently and are simple (to use)" (Field notes, 11 March 2016) and "without chemical fertilizers, (trees) do not grow well” (Field notes, 3 March 2016). With intensive use of chemical inputs, these investors are able to log in three or four years, when foreign companies usually take six years or even longer to harvest. ${ }^{31}$ Additionally, some intimate grabbers plant trees more densely compared to their foreign counterparts, as admitted by a local grabber (Field notes 20 March 2015). Thus, sometimes, according to local affected villagers, one may easily differentiate trees planted by intimate land grabbers from those planted by foreign companies, as shown in Figure 2.

Figure 2 eucalyptus trees planted by an “intimate land grabber” (left) and by Stora Enso (right)

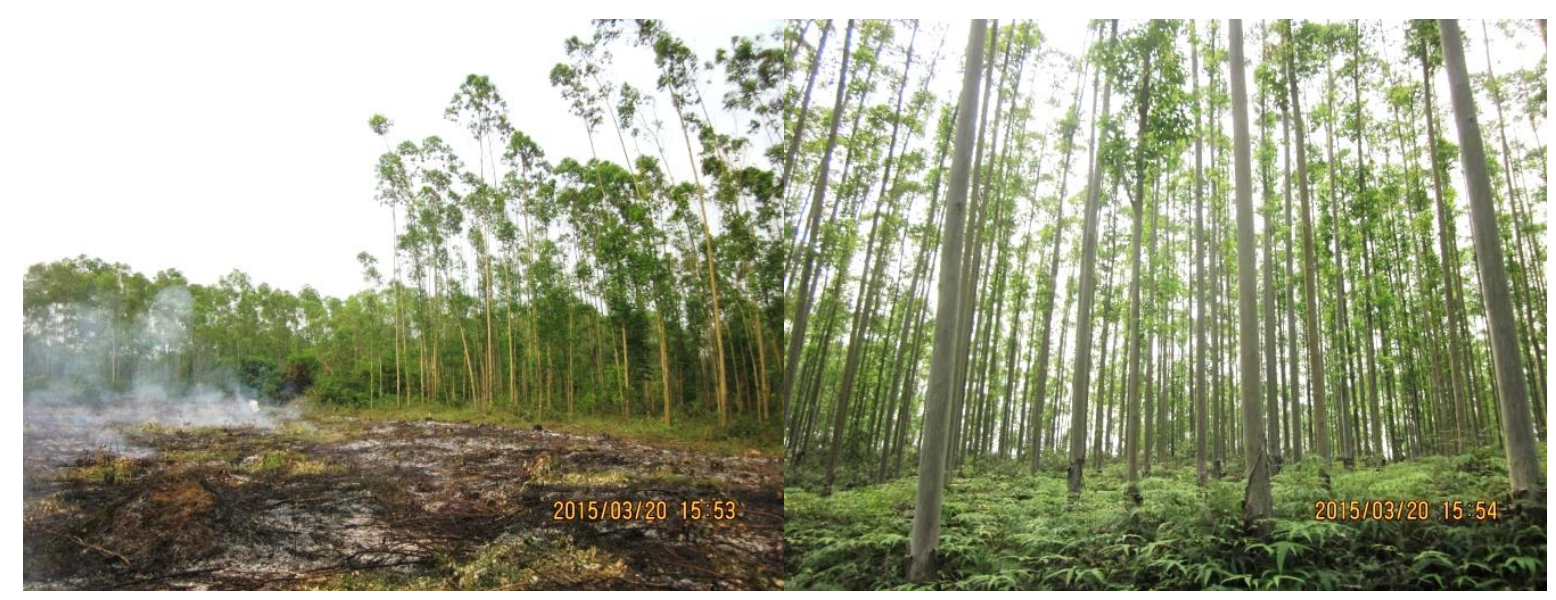

Source: photos taken by the author during the fieldwork in 2015.

This difference is linked with the distinct public attention given to each type of investor. Compared with big companies, especially foreign ones, individual investors are much less exposed to the public. They do not need to follow strict ecological standards or receive environmental assessments from international NGOs as their foreign counterparts do. Thus, some of these local individual investors are able to cultivate the trees in a more profitable way as mentioned above, despite the fact that this might sometimes bring more significant environmental destruction.

\footnotetext{
${ }^{31}$ Data about the harvest time of these local individual investors are from interviews with a few investors during my fieldwork in 2015 and 2016. And data about foreign companies harvest time are mentioned in interviews both with employees from foreign companies and with workers of a state-owned farm (Field notes, 3 and 19 March 2015, and 29 March 2017).
} 
Therefore, the impact of intimate land grabbers in a few cases is not less, but at times even more significant than that of large-scale external grabbers. Once intimate land grabbers have acquired the land, their fellow villagers, dispossessed from the collectively-own land that they originally used or could potentially use, are rarely employed on the ITPs. Furthermore, due to a few individual investors' intensive production practices, their neighbours have to deal with more serious adverse impacts on the local ecology, which in turn increasingly affects their agro-production and the corresponding income from it.

\subsection{Further implications of intimate land grabbing}

In addition to these above impacts, these intimate land grabs also tend to have impacts on agrarian transformation. A trend is now taking place in contemporary China, where mass numbers of villagers are giving up farm work in rural areas and migrating to urban areas as cheap wage labour in the industrial sector to facilitate capital accumulation (Arrighi 2007). However, the intimate land grabbing denotes an adverse flow of labour and capital, as a few villagers gave up wage jobs in the urban areas and used the income earned from industrial sector to invest in ITP sector.

When these grabbers accumulate based on their land control and become better-off, other villagers, especially the marginalised, are more vulnerable. Thus, the social differentiation is further deepened. Such dynamics of labour and capital show a circular rather than a linear city-countryside relationship, which merits further research.

\section{Conclusion}

In sum, this paper explores the dynamics of intimate land grabs, which have been largely overlooked in the current literature and debates on land grabbing. By analysing the land grabs initialled by local villagers targeted for the ITP sector in Guangxi, this piece demonstrates three key points. First, a few local villagers did acquire land from their own/nearby community for the cultivation of eucalyptus with the rise of ITP sector and under the certain institutional and structural context in rural China. To gain control over land, these villagers employ both economic and extra-economic means based on their privileged access to information and resources (particular financial and/or labour resources). Their land accumulation is at the expenses of their fellow villagers and kin. Thus, within land grabs, villagers can also be grabbers rather than simply victims or resisters.

Second, although these intimate land grabs emerged at relatively small scales, they do occur commonly in Guangxi and maybe also in other regions all over the worlds. These land grabs received much less public attention compared with large-scale ones. So, when large-scale land investors follow stricter environmental standards due to their high visibility, a few intimate grabbers are observed to cultivate trees a more intensive way, which tends to cause environmental destruction. This means that smallscale land grabs are not necessarily less significant than large-scale ones.

Third, these land grabs are dominated by local villagers. But these villagers' capability to gain and maintain control over land is not always weaker than that of capital-abundant (outside) corporations. In fact, due to certain institutional settings and social and geographic proximity, it is sometimes even stronger. Furthermore, compared with their corporate-dominated counterparts, these local actors sometimes are observed to bring even more serious negative impacts due to their certain production modes out of their interests. In this sense, land grabs initialled by local actors are not always less, but at times more, harmful to local communities.

These are critical reminders to go beyond the dichotomies of "small vs. large”, "outsider vs. local actors" and "victims vs. grabbers" and instead focus on the political economic and ecological dynamics of land control and land use changes. In other words, this paper argues that the importance of a land grab is neither represented by its scale nor the identity of the grabber(s), but by its de facto consequences, especially the distribution of the costs and benefits. 


\section{References}

Alonso-Fradejas, A. "Land control-grabbing in Guatemala: the political economy of contemporary agrarian change." Canadian Journal of Development Studies-Revue Canadienne D Etudes Du Developpement 33, no.4 (2012):509-528.

Alonso-Fradejas, A. "Anything but a story foretold: multiple politics of resistance to the agrarian extractivist project in Guatemala." Journal of Peasant Studies 42, no.3-4(2015):489-515.

Arrighi, Giovanni. "Adam Smith in Beijing." Lineages of the Twenty-First Century, London. New York. 2007.

Bernstein, Henry. Class dynamics of agrarian change. Vol. 1: Kumarian Press. 2010.

Borras Jr, Saturnino M, Ruth Hall, Ian Scoones, Ben White, and Wendy Wolford. "Towards a better understanding of global land grabbing: an editorial introduction." The Journal of Peasant Studies 38, no.2 (2011):209-216.

Borras, S. M., and J. C. Franco. "Global Land Grabbing and Political Reactions 'From Below'." Third World Quarterly 34, no.9 (2013):1723-1747.

Borras, S. M., J. C. Franco, S. Gomez, C. Kay, and M. Spoor. "Land grabbing in Latin America and the Caribbean." Journal of Peasant Studies 39, no.3-4(2012):845-872.

Brautigam, Deborah, and Sigrid-Marianella Stensrud Ekman. "Briefing Rumours and realities of Chinese agricultural engagement in Mozambique." African Affairs 111, no.444( 2012):483-492.

Calder, Ian R. "2 Eucalyptus, water and the environment."In Eucalyptus: The Genus Eucalyptus. ed. J. J. Coppen, 36-51. Asterdam: Harwood Academic Publishers. 2003.

Calder, Ian R, Paul TW Rosier, KT Prasanna, and S Parameswarappa. "Eucalyptus water use greater than rainfall input-possible explanation from southern India." Hydrology and Earth System Sciences Discussions 1, no. 2(1997):249-256.

Dell'Angelo, J., D'Odorico, P., Rulli, M. C., \& Marchand, P. The tragedy of the grabbed commons: Coercion and dispossession in the global land rush. World Development 92(2017):1-12.

De Schutter, Olivier. "How not to think of land-grabbing: three critiques of large-scale investments in farmland." The Journal of Peasant Studies 38, no.2 (2011):249-279.

Edelman, M. "Messy hectares: questions about the epistemology of land grabbing data." Journal of Peasant Studies 40, no.3 (2013):485-501.

Edelman, Marc. Peasants against globalization: rural social movements in Costa Rica: Stanford University Press. 1999.

Friis, C., \& Nielsen, J. Ø. Small-scale land acquisitions, large-scale implications: Exploring the case of Chinese banana investments in Northern Laos. Land Use Policy 57 (2016):117-129.

Gerber, Julien-FranÇOis, and Sandra Veuthey. "Plantations, Resistance and the Greening of the Agrarian Question in Coastal Ecuador." Journal of Agrarian Change 10, no.4(2010):455-481.

Hairong, Yan, and Chen Yiyuan. "Agrarian capitalization without capitalism? Capitalist dynamics from above and below in China." Journal of Agrarian Change 15, no.3 (2015):366-391.

Hall, D. "Land grabs, land control, and Southeast Asian crop booms." Journal of Peasant Studies 38, no.4(2011):837-857.

Hall, Derek, Philip Hirsch, Tania Li, and Tania Li. Powers of exclusion: Land dilemmas in Southeast Asia: NUS Press. 2011.

Hall, R., M. Edelman, S. M. Borras, I. Scoones, B. White, and W. Wolford. "Resistance, acquiescence or incorporation? An introduction to land grabbing and political reactions 'from below'." Journal of Peasant Studies 42, no. 3-4 (2015):467-488.

Huang, P. C. C., G. Yuan, and Y. S. Peng. "Capitalization without Proletarianization in China's Agricultural Development." Modern China 38, no.2(2012):139-173.

Jacka, Tamara. "Translocal family reproduction and agrarian change in China: a new analytical framework." The Journal of Peasant Studies(2017):1-19.

Kröger, Markus. "The Expansion of Industrial Tree Plantations and Dispossession in Brazil." Development and Change 43, no.4 (2012):947-973.

Lenin, Vladimir I. "The differentiation of the peasantry." Rural Development: Theories of Peasant Economy and Rural Change (1982):130-138. 
Levien, Michael. "The land question: special economic zones and the political economy of dispossession in India." Journal of Peasant Studies 39, no.3-4 (2012):933-969.

Li, Ming. Dynamic studies about the Forest Rescource in Guangxi [Guangxi Senlin Ziyuan Dongtai Yanjiu], Guangxi University. 2008.

Li, T. M. "Centering labor in the land grab debate." Journal of Peasant Studies38, no.2 (2011):281-298.

$\mathrm{Li}$, Tania Murray. Land's end: Capitalist relations on an indigenous frontier: Duke University Press. 2014.

Liu, Yang. APP Guangxi Plantation-Pulp-Paper Integration Proejct, 2010.accesed on 7th July 2016. http://finance.people.com.cn/GB/67723/67730/12680269.html.

Lungo, A. Del, J. Ball, and J. Carle. Global planted forests thematic study. Results and analysis. In Planted Forests and Trees. ROME: FAO. 2006.

Mamonova, N. "Resistance or adaptation? Ukrainian peasants' responses to large-scale land acquisitions." Journal of Peasant Studies 42, no.3-4 (2015):607-634.

Martiniello, G. "Social struggles in Uganda's Acholiland: understanding responses and resistance to Amuru sugar works." Journal of Peasant Studies 42, no.3-4 (2015):653-669.

McAllister, K. E. "Rubber, rights and resistance: the evolution of local struggles against a Chinese rubber concession in Northern Laos." Journal of Peasant Studies 42, no.3-4 (2015):817-837.

McCarthy, John F. "Processes of inclusion and adverse incorporation: oil palm and agrarian change in Sumatra, Indonesia." The Journal of Peasant Studies 37, no.4 (2010):821-850.

McKay, B., and G. Colque. "Bolivia's soy complex: the development of 'productive exclusion'." Journal of Peasant Studies 43, no.2 (2016):583-610.

Moreda, T. "Listening to their silence? The political reaction of affected communities to large-scale land acquisitions: insights from Ethiopia." Journal of Peasant Studies 42, no.3-4 (2015):517539.

Moreda, T., and M. Spoor. "The politics of large-scale land acquisitions in Ethiopia: state and corporate elites and subaltern villagers." Canadian Journal of Development Studies-Revue Canadienne D Etudes Du Developpement 36, no.2 (2015):224-240.

Oberlack, C., Tejada, L., Messerli, P., Rist, S., \& Giger, M. "Sustainable livelihoods in the global land rush? Archetypes of livelihood vulnerability and sustainability potentials." Global environmental change 41 (2016):153-171.

O'Brien, Kevin J, Lianjiang Li, Douglas McAdam, Sidney G Tarrow, and Charles Tilly. Rightful resistance in rural China: Cambridge University Press Cambridge. 2006.

Oya, C. "Methodological reflections on "land grab' databases and the "land grab' literature "rush'." Journal of Peasant Studies 40, no.3 (2013):503-520.

Pang, Zhenghong. The General Development Status of Eucalyptus Tree Plantation in Guangxi Province 2006.

Schneider, M.,. What, then, is a Chinese peasant? Nongmin discourses and agroindustrialization in contemporary China. Agriculture and Human Values, 32, no.2 (2015):331-346

Scoones, I., R. Hall, S. M. Borras, B. White, and W. Wolford. "The politics of evidence: methodologies for understanding the global land rush." Journal of Peasant Studies 40, no.3 (2013):469-483.

Scott, James C. The moral economy of the peasant: Rebellion and subsistence in Southeast Asia: Yale University Press. 1977.

Sikor, T. Financing household tree plantations in Vietnam: Current programmes and future options. Bogor, Indonesia: Center for International Forestry Research (CIFOR). 2011.

Spoor, Max. "AGRARIAN REFORM AND TRANSITION: What can we learn from 'the East'?" Journal of Peasant Studies 39, no.1 (2012):175-194.

StoraEnso. Progress Book. In Stora Enso’s Annual Report 2015: Stora Enso. 2016.

Wei, Jichuan. "The High Eucalyptus Trees and the Timber Production in Southern China (桉树指天高 产木看南国)." 2011.

White, B., S. M. Borras, R. Hall, I. Scoones, and W. Wolford. "The new enclosures: critical perspectives on corporate land deals." Journal of Peasant Studies 39, no.3-4 (2012.):619-647.

$\mathrm{Xu}$, Yunan. "Politics of inclusion and exclusion in the Chinese industrial tree plantation sector: The global resource rush seen from inside China." Journal of Peasant Studies (2018):1-25 
Zhang, Q. F. "The Political Economy of Contract Farming in China's Agrarian Transition." Journal of Agrarian Change 12, no.4 (2012):460-483.

Zhang, Q. F., Q. G. Ma, and X. Xu. "Development of land rental markets in rural Zhejiang: Growth of off-farm jobs and institution building." China Quarterly 180 (2004):1050-1072.

Zoomers, Annelies. "Globalisation and the foreignisation of space: seven processes driving the current global land grab." The Journal of Peasant Studies 37, no. 2 (2010):429-447. 